\title{
Commodification broadcast television program on local television in Bandung, West Java
}

\author{
Aep Wahyudin ${ }^{1, *}$ \\ ${ }^{1}$ Faculty of Da'wa and Communication, Islamic State University of Sunan Gunung Djati Bandung, \\ Indonesia
}

\begin{abstract}
The media has now become a tool that performs many functions, beyond its function as a conduit of information to the public. As an industry, television programming impressions always count with the economic calculations that led to the result of profit. Media with strengths and opportunities will see any loopholes that benefit the industry into a viable commodity. The commodification in a critical view of the media sees the commodities and commodification with two things that connect the object and process. It is one indicator of global capitalism that is now taking place. Commodification is the transformation of the shape of the relationship, which is initially trafficked into things that are free of the commercial nature of the relationship.
\end{abstract}

\section{Introduction}

In less than two decades, the world of television and entertainment in Indonesia experienced a remarkable development rapidly. The proliferation of private television in Indonesia, making human beings can survive television personality must exist for their own companies, because they differ with subsidized government television. This fact is the private television demanding to search for life and a large profit. Given the media industry is one of the promising businesses. But in fact the capital creativity they can take heart in the wider community to become loyal viewers. What they presented turned out favored, even though there are so many forms of commodification made by the personnel of private television.

The media is far different with BBC. BBC has deliberately oriented specific channels to certain age groups such as youngsters and children in order to attract viewers who are drifting away in the competition. Media has now become a tool that performs many functions, beyond its function as a conduit of information to the public. Media are in triangulation state, market, civil society. Media that linking these three components, the reform era triangulation relationship is dominated by the market, whereas formerly dominated by the state. Media liaison these three components, and must not be located or in favor of just one component [1].

As time becomes business promising media. The media industry can be used as a propaganda tool and for commercialization. Especially with the proliferation of private

\footnotetext{
*Corresponding author: fwahyu2000@yahoo.com
} 
television which certainly does not get subsidies from the government, so they have to rack my brain to be able to survive and continue to exist in the television world, is to create programs that dance that the public likes what the television present, so the profits (profit) can they. One of the commodification of land except entertainment, talk shows, reality shows and more prevalent on television is a religious impression. Religion with a variety of formats into a land that always never dry to be explored at once exploited in various forms impressions. Modern society is hungry for spiritual cleansing would make religion a mooring end to solve life's problems. The rise tausia' $h$ business since the early $2000 \mathrm{~s}$ became one of the clear evidence of how religion is now a basic human need. Especially in the moments of the annual ritual of some sort of Ramadan comes, religion turned into a business area that inspired many creative people to produce events that can suck the audience, because it is not uncommon that ultimately it was stuck into the game symbols away from religious values pure.

In the context of popular culture, mystique soap opera is just a phase of the ongoing commodification of culture. The television station made programs for mystical scented soap opera, and certainly not just a passion born of mere propaganda. More than that, such broadcasts are also laden trade policy because it provides enough profit from the business side. Absorb enough ad impressions lot plus persistence models thus give concrete evidence of ulterior motives are behind view program.

\section{Literature review}

Local private television media in West Java, could not be separated with the business, the business interests that will enable local television as an industry have to chase profits. In this aspect, the television will make and create programs to gain commercial advantages. In fact, Supratman said that local television function is to present local genius television programs. In the media industry are found examples of symptoms of commoditization [2]. The media content is made an extent as to attract the market so-called commodity markets could be sold then distributed audience then also be impact on the standardization of commodity goods. By the existence of feature, platform, and the newest function, the way the audience access the media is changing [3]. The broader impact is when the symptoms of the modification and standardization have experienced modification means that these commodities are scattered and spread in a massive people's lifestyles. Public or community can easily reflect his personal life with what is in the media. Commodification according vocabulary in Marxist terms is a form of transformation of the relationship, which was originally free from the things that are trafficked into the commercial nature relationship. Commodification described as a way of capitalism by bringing accumulated his capital purposes, or simply can be described as a change in the value of the function or to become an exchange. There are two dimensions of the relationship commodification in communication: 1 . The process of communication and technology contribute to the general process of commodification in the overall economy; 2 . The process of commodification at work in society as a whole penetrate communication processes and institutions, so that development and contradictions in the process of commodification affect communication as a social practice.

\section{Data analysis}

The following overview shows the composition of the local TV broadcast: 
Table 1. Format Composition Program Local TV Broadcast

\begin{tabular}{|c|c|c|c|c|c|c|c|c|c|c|}
\hline \multirow{2}{*}{$\begin{array}{c}\text { TV } \\
\text { Statio } \\
\mathbf{n}\end{array}$} & \multicolumn{2}{|c|}{$\begin{array}{c}\text { Information } \\
\text { Program } \\
\end{array}$} & \multicolumn{2}{|c|}{$\begin{array}{c}\text { Education } \\
\text { Program }\end{array}$} & \multicolumn{2}{|c|}{$\begin{array}{c}\text { Entertainme } \\
\text { nt Program }\end{array}$} & \multicolumn{2}{|c|}{ Others } & \multicolumn{2}{|c|}{ Amount } \\
\hline & $\begin{array}{c}F \\
\text { (Hour } \\
\text { ) }\end{array}$ & $\%$ & $\begin{array}{c}F \\
\text { (Hour } \\
\text { ) }\end{array}$ & $\%$ & $\begin{array}{c}F \\
\text { (Hour } \\
\text { ) }\end{array}$ & $\%$ & $\mathbf{F}$ & $\%$ & $\begin{array}{c}\text { F } \\
\text { (Tot } \\
\text { al } \\
\text { Hour } \\
\text { ) }\end{array}$ & $\begin{array}{l}\quad \% \\
\text { (total } \\
\text { percentag } \\
\text { e) }\end{array}$ \\
\hline$B T V$ & 49 & 46.7 & 5 & 4.7 & 52 & 48.6 & 0 & 0 & 106 & 100 \\
\hline$S T V$ & 34 & 31.3 & 4 & 3.7 & 47 & 43.3 & $\begin{array}{l}2 \\
3 \\
\end{array}$ & 21.6 & 108 & 100 \\
\hline PJTV & 36 & 28.2 & 12 & 14 & 58 & 46 & $\begin{array}{l}1 \\
5\end{array}$ & 12 & 127 & 100 \\
\hline $\begin{array}{l}\text { Amou } \\
n t\end{array}$ & 119 & $\begin{array}{l}34,9 \\
0\end{array}$ & 27 & $\begin{array}{l}7,9 \\
1\end{array}$ & 157 & $\begin{array}{l}46,0 \\
5\end{array}$ & $\begin{array}{l}3 \\
8\end{array}$ & $\begin{array}{l}11,1 \\
4\end{array}$ & 341 & 100 \\
\hline
\end{tabular}

\section{Discussion}

Analysis of the table above, should programs broadcast content that is inserted into the program classification factual and non-factual is the encouragement of provision of broadcast according to the law of broadcasting and regulatory programs broadcast in the P3SPS, which can encourage and be inspirations program based factual and non-factual. However, these programs are for the benefit of the market and the commodification of advertisers only. This is the commodification of culture in the Program of Bandung Raya (BTV). Bandung Raya TV is a local news program that presents the news accurately packaged and populist from the coverage of events and happenings that occur around Bandung or West Java. Contain actual news and event program is aired every day.

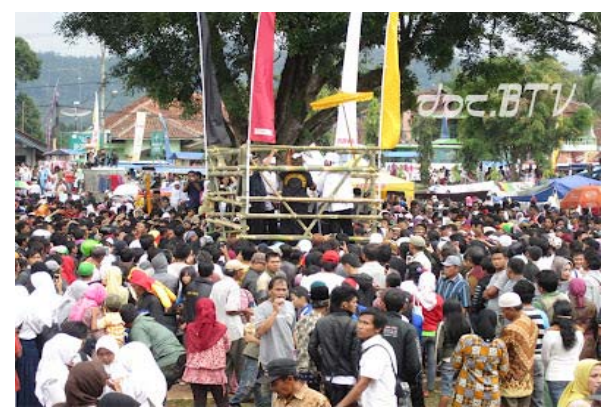

Fig. 1. Regarding Snapshot Image on Bandung Raya TV

There are also the commodification of Religion and Health (Special Treatment) on three Program Local Television (BTV, PJTV, STV). Program therapies and alternative medicine is an interactive talk show that discussed the treatment alternative. In this event featured an informant (an expert in alternative medicine) which discusses how the treatment he did. "This event in addition to taking an informant as a therapist (but not a doctor), there is also a patient ever cured or healed by therapists and issued earlier testimony. In other contexts, this event sells the drug in the form of herbs and the like as well as the identity and address of where the drug can be obtained. After giving a presentation or explanation of what and how the medication, then opened the interactive dialogue, which allows viewers to ask 
questions or consultations by telephone. Usually the problem, when the therapist had to provide treatment that are "unseen" or paranormal, so it is feared falls on mystical impressions which are prohibited by P3 and SPS. Therapy and treatment program that took place in Bandung TV for instance in the Pearl Therapy program, Dr. Kita, Special Dialogue, the Alternative Healthy with Bandung TV, Totok Clinic Stomach Mega Power, Mayang Tea Clinic. This display program packaged in the form and format some program, then presented in several different packaging program title, treatment program was aired on average in the afternoon, at 16.00 up to $17.00 \mathrm{pm}$.

Treatment programs are impressions of therapy or treatment of various diseases complained and submitted by viewers either directly or through his phone. Almost all local television programs of alternative medicine impressions and some of them could be considered mystical. Most radio also broadcast ads this treatment.

Television is industry entertainment, and entertainment is the creativity of artistic freedom. Apparently, it is already an advanced adage for national television, including the local television in Bandung, West Java. Of course, this problem can be seen and studied from broadcasts the program. In the context of the commodification of entertainment this, Music Holic, SoundXplore, Piloks, 8Beat Euy, Momentoz De Paz, Sinemania make and make entertainment programs packaged in a show, concert, music, and fromat other programs, which are more likely perform aspects of sensuality, sex, gossip, vulgarity, pornography, and other displays that are inconsistent with public ethics.

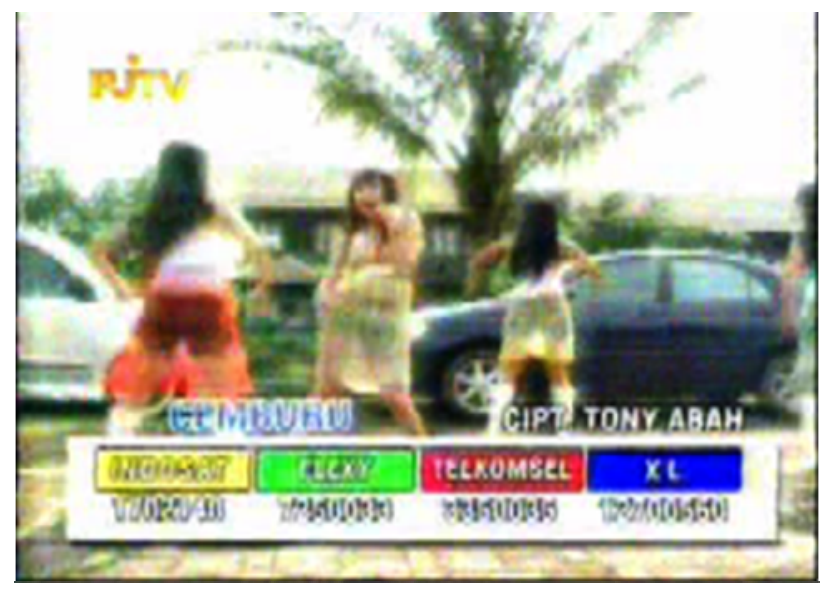

Fig.2.Commodification Entertainment Program 'music' PJTV (2010)

Commodification entertainment of the show program "Music Holic", "SoundXplore", Piloks, "8Beat Euy" is, by showing clearly the visualization of scenes and action swings Nudity, exposing the sensitive for the public, perform movements erotic and challenging (or such movements having sex), singing a song with the sounds erotic, and also respiratory sigh-sigh sensual, performance dress in skimpy outfits and sexy, coupled with the lyrics and lyric songs conformity, sex and vulgar.

\section{References}

1. N. Yoshiko, Y. Ritsu. Public Broadcasting and Changing Audiences in The Digital Era: Services and Social Mission. (NHK Broadcasting Studies, 2008) 
2. L. P. Supratman.. Observation Journal. The representation of local wisdom at regional news program 'Kalawarta' on TVRI West Java. Volume 14 Number 1 Year 2016. ISSN 1412-5900. Page 27. (2016)

3. R. Kubey. Media literacy in the information age: current perspective, information and behavior Volume 6. (New Jersey, USA: Transaction Publishers, 2001) 